\title{
Flyktninger har økt risiko for psykose
}

\section{Flyktninger har 3-4 ganger høyere risiko for å utvikle psykose enn per- soner født i Sverige. Dette viser en ny studie.}

Flyktninger har økt risiko for posttraumatisk stressyndrom, og flere studier har vist at innvandrere er mer utsatt for å utvikle schizofreni og andre psykotiske lidelser enn de «innfødte». Men det har vært uklart om flyktninger som undergruppe er enda mer utsatt for psykoselidelser.

I en svensk retrospektiv kohortstudie (1) ble over tre millioner mennesker fulgt fra 14. leveår eller fra det tidspunkt de ankom Sverige og frem til tidspunktet for diagnostisert ikke-affektiv psykose, død, emigrasjon eller studiens avslutning. Personer uten oppholdstillatelse ble ekskludert. Over 3700 til-

feller av ikke-affektiv psykotisk lidelse ble identifisert over rundt 8,9 millioner personår. Insidensen per 100000 personår var rundt 39 hos svenskfødte personer med to svenskfødte foreldre, 80 hos migranter som ikke var flyktninger og 126 hos flyktninger. Etter justering for konfunderende faktorer hadde flyktninger $ø$ kt risiko for psykose sammenliknet med både svenskfødte (hasardrisiko 2,9; 95 \% KI 2,3-3,6) og migranter som ikke var flyktninger (HR 1,7; $95 \%$ KI 1,3-2,1). Risikoen var høyere hos menn enn hos kvinner og høyere blant immigranter fra land sør for Sahara både hos flyktninger og hos migranter uten flykt-

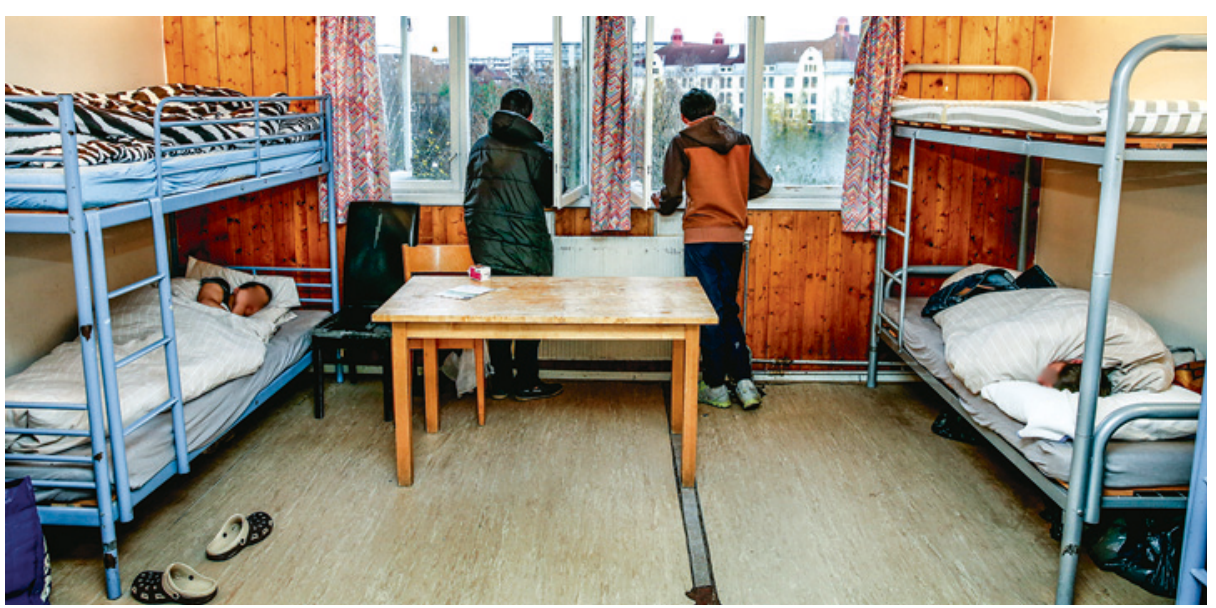

Torshov transittmottak i Oslo for enslige mindreårige asylsøkere mellom 15 og 18 år. Foto: Stein J. Bjørge/Aftenposten/NTB scanpix

\section{Kjemisk reprogrammering av celler}

\begin{abstract}
En cocktail av ni kjemiske forbindelser kan brukes til å reprogrammere humane hudceller til hjerteceller. Kan dette prinsippet brukes for regenerativ terapi av hjertesykdom?
\end{abstract}

I 2012 ble nobelprisen i fysiologi eller medisin tildelt forskere som kunne restarte og omprogrammere celler. En ny studie viser at reprogrammering kan styres ved hjelp av kjemiske forbindelser (1). Humane fibroblaster ble eksponert med ni kjemiske forbindelser for å generere hjerteceller. Cocktailen kunne indusere eller forsterke uttrykk av gener som styrer kardiogenesen.

Sammenligning av hudcellene og de «nye» cellene viste epigenetiske endringer i kromatinstrukturen, med påfølgende regulering av genuttrykk som reflekterte cellefunksjonen. Homogeniteten i genuttrykket hos nyprogrammerte hjerteceller ble verifisert med revers nukleinsyreamplifisering på enkeltceller. I funksjonelle tester ble det vist kontraksjon i $97 \%$ av cellene in vitro. Reprogrammerte hjerteceller ble transplantert i musehjerte med indusert infarkt, og etter to uker hadde cellene delvis dekket infarktområdet.

- Reprogrammering av celler ved hjelp av genetisk modifisering har vært kjent $i$ ti år, men de siste årene er det blitt kjent at reprogrammering også kan gjøres ved å behandle celler med kjemiske stoffer, sier Jan Øivind Moskaug, som er professor ved Norsk senter for stamcelleforskning, Universitetet i Oslo.

- Denne studien viser at humane hudceller kan reprogrammes til hjertemuskelceller i laboratoriet og bedrer hjertefunksjonen ved transplantasjon i mus. Cellene kontraherer ningbakgrunn. Dette kan kanskje skyldes at personer fra disse landene i større grad var blitt eksponert for psykososialt stress før de migrerte, uavhengig om de var flyktninger eller ikke, mener forfatterne.

- Dette er den første studien som viser at risikoen for psykose er større hos flyktninger fra mange land, sier Akiah Ottesen Berg, som er psykolog og forsker ved NORMENT K.G. Jebsen Senter for psykoseforskning ved Oslo universitetssykehus og Universitetet i Oslo. - I studien ble det kontrollert for en rekke vesentlige variabler, slik som alder, kjønn, sosioøkonomisk status og urbanitet, men man har ikke tatt med mulige komorbide diagnoser, slik som posttraumatisk syndrom, påpeker Berg, som likevel mener at funnene er av stor betydning ettersom flyktningstrømmen til Europa har økt i de senere år.

- Funnene er overførbare til norske forhold, sier Berg. - I Norge har man funnet at innvandrere som utvikler psykose, kommer senere til behandling, har mer alvorlige symptomer og dårligere funksjon enn pasienter uten innvandrerbakgrunn. Den aktuelle studien viser at vi trenger et behandlingstilbud for flyktninger og nyankomne innvandrere med målrettet tidlig intervensjon mot psykotiske lidelser, sier Berg.

\section{Ketil Slagstad \\ Tidsskriftet}

Litteratur

Hollander AC, Dal H, Lewis G et al. Refugee migration and risk of schizophrenia and other non-affective psychoses: cohort study of 1.3 million people in Sweden. BMJ 2016; 352: i1030. og har elektrofysiologiske egenskaper som ligner hjertemuskelceller. Stoffene som benyttes, de fleste hemmere av kjente signalveier i cellene, er kommersielt tilgjengelig. Man ser for seg muligheten av å behandle hjerteinfarkt ved å injisere reprogrammeringsstoffene $\mathrm{i}$ hjertet og dermed reprogrammere hjertefibroblaster til hjertemuskelceller. Utfordringen er å administrere flere stoffer samtidig i riktige konsentrasjoner. Det gjenstår også å vise at man ikke får uønskede epigenetiske endringer $i$ andre celler ved slik reprogrammering, sier Moskaug.

\section{Ruth Halsne}

Tidsskriftet

\section{Litteratur}

Cao N, Huang Y, Zheng J et al. Conversion of human fibroblasts into functional cardiomyocytes by small molecules. Science 2016; 352: 1216-20. 